\title{
An Content Analysis of the Definition of Critical Thinking
}

\author{
Fuyun Geng ${ }^{1}$ \\ ${ }^{1}$ Faculty of Education, Southwest University, Chongqing, China \\ Correspondence: Fuyun Geng, Faculty of Education, Southwest University, Chongqing, Beibei district, \\ Tiansheng road, No. 2, Institution of Higher Education, China. Tel: 86-1-592-358-5423. E-mail: \\ 948845055@qq.com
}

Received: July 8, 2013 Accepted: August 19, 2014 Online Published: September 29, 2014

doi:10.5539/ass.v10n19p124

URL: http://dx.doi.org/10.5539/ass.v10n19p124

\begin{abstract}
Based on 64 definitions of critical thinking in the recent study, it can be concluded that scholars take judgment, argument, questioning, information processing, problem solving, meta-cognition, skill and disposition as the nature of critical thinking. Scholar's disciplinary background directly affect their opinions of critical thinking, interdisciplinary research should be paid more attention to promote the development of critical thinking.
\end{abstract}

Keywords: critical thinking, the nature of critical thinking, discipline

\section{Introduction}

Although most scholars agree that the improvement of the critical thinking is an important educational objective, they often disagree on exactly what critical thinking is (Bensley, 2011). The thought of critical thinking came from the Greek philosopher Socrates (469-399 B. C.), developing a special kind of dialogue that used reasoning to examine opinions, because he emphasized reflection on the quality of the belief and thinking (Ennis, 1987; Paul, 1993). In fact, this is scholar's inference. In all the works, Socrates didn't refer to the term "critical thinking". Goodwin Watson and E. M. Glaser did it in 1941, published the Watson-Glaser Tests of Critical Thinking. They try to product a definition of critical thinking. After more than three decades of discussions about the critical thinking, scholars paid too much attention to critical thinking. As of July 4, 2014, google scholar lists some 3330, 000 titles and Amazon.com lists 47, 434 titles on critical thinking. It is a truth that critical thinking is an unquestionable good for university, college student, even every a citizen. Although we all agree that critical thinking is an important element of Western thought, even traceable to Socrates, scholars have battled over whether the Left or Right critical thinking, based on their understanding.

Almost every famous scholar has a definition of critical thinking (e.g. , Beyer, 1995; Chance, 1986; Dong, 2012; Ennis, 1987; Facial, 2008; Fisher, 2001; Alpenhorn, 1998; Johnson, 1993; Kurfiss, 1988; Lipman, 1991; Paul, 1999, 2006; Scriven, 2000; Zhang, 1989; Zhu, 2002). Glaser thought critical thinking invovled certain attuides (Glaser, 1941); Robert Ennis defined critical thinking as "reasonable, reflective thinking focused on deciding what to believe or do " (Ennis, 1987), it was thought of following up Dewey who introduced the term "reflective thinking"; APA Delphi Panel acknowledged that critical thinking is related to problem solving, decision making and creative thinking (Facione, 1990). As every coin has both sides, an abundance of research makes a better understanding of the critical thinking; at the same time, because of persistent complaints from those working in various disciplines about the need to refine its conceptualization (e.g. Bensely, 2009; Cody, 2006; Johnson, 1992; Petris, 2004; Riddell, 2007; Williams \& Worth, 2001), disagreements about the nature of critical thinking continue. As the review above suggest, critical thinking remains a construct in transition, in need of future integration of concepts from philosophy, psychology, education and other disciplines (Bensely, 2011).

\section{Method}

Content analysis is classified statistics with using the quantitative and descriptive explanation according to these categories of digital. Content analysis was employed in this study. So, firstly, 64 classic and typical definitions of critical thinking were collected by in Chinese and English dictionary, academic journal, report, dissertation and so on. Secondly, according to nature of every definition, discipline, the time of appearance, these definitions were encoded and classified. The nature of critical thinking was divided into seven items, they were judgment, argument, questioning, problem solving, information processing, meta-cognitive, skill and disposition; according to Chinese discipline- standard, we have thirteen disciplines; the time of appearance was from 1941 to 2013. In 
1941, the first definition appeared. In 2014, we didn't find any definition of critical thinking. Thirdly, according to every item above, if the definition had the item, it would be recorded by "1". At last, made a total and form charts. Forth, interpret figures.

\section{Results}

\subsection{The Nature of Critical Thinking}

Most scholars have different definitions of critical thinking; the nature of critical thinking also is different in their opinions. The nature of something is its basic quality or character. In a definition, there is one or two key words can embody the nature of it. So, there must be key words of the nature of critical thinking. In Socates's and Dowey's opinions, the nature of critical thinking is "reflection on the quality and relief". However, Plato (428-347 B.C.) and Aristotle (384-322 B.C.) emphasized "syllogistic reasoning", "dialectic" and "art of thinking" on the importance of critical thinking. In the Nineteenth Century, Kant (1724-1804) thought that the source of the knowledge could influence on the critical thinking. At the Twentieth of Century, Sumner discussed the importance of "critical habit". In a word, the focus on critical thinking is different.

Figure 1 gives us a clear description of the nature of critical thinking. The key words of the nature of critical thinking are "judgment", "argument", "questioning", "problem solving", "information processing", "meta-cognitive", "skill and disposition". In all of the nature of definition, there is 19 about "judgment". In another word, the number of judgment is the most. The number of "skill and disposition", "meta-cognitive", "argument", "problem solving", "information processing", "questioning" in turn is 10, 9, 7, 7, 6, 6. The number of the nature questioning and "information processing" is the least. Except the number of the nature of judgment, there is not too much difference among the other nature. This figure give us a shock, it made us think over that why the most number of the nature is judgment.

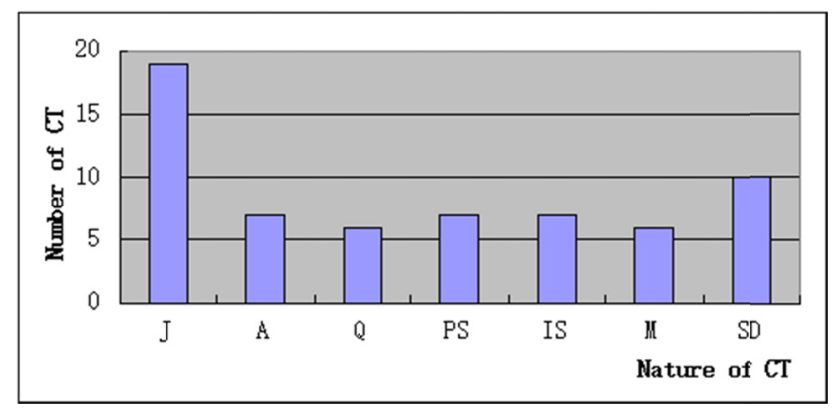

Figure 1. The number of the nature of critical thinking

Note: J-- judgment, A--argument, Q--questioning, PS--problem solving, IS--information processing, M--meta-cognition, SD--skill and disposition

\subsection{The Disciplines of Critical Thinking}

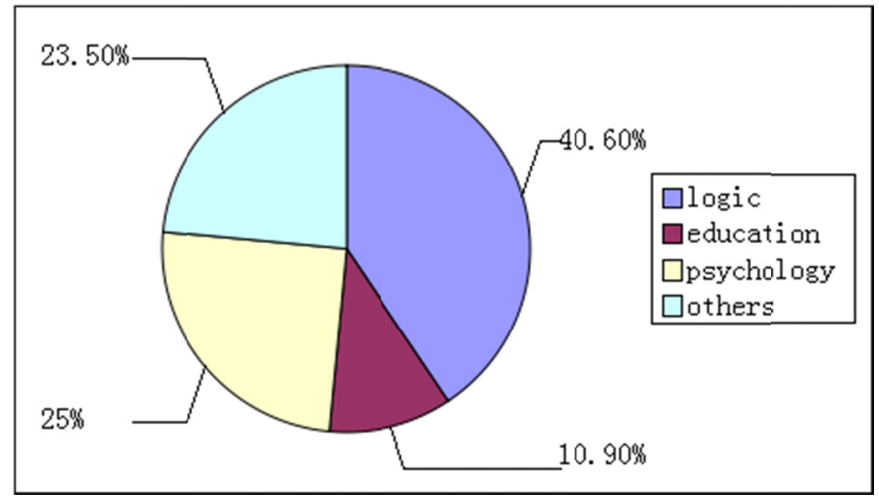

Figure 2. The disciplines of critical thinking

Scholar's discipline knowledge directly what they understand the critical thinking. Scholars, from the Greek to the modern society, from the famous Socrates to nameless person, discussed the topic of critical thinking with 
discipline knowledge. In the ancient society, most of them are philosopher. In modern society, the discipline states of scholars become more and more complicated. They are psychologists, sociologists, educators and so on. Most of them have multiple disciplines background, such as John Dewey who is philosopher and educator, Peter Facione who is psychologists and educator, even Aristotle whose works contain more than three disciplines, including physics, metaphysics, poetry (including drama), music, biology, animal science, logic, politics, government, and ethics.

In figure 2, 23.50\% of the definition does not have a clear discipline; $40.60 \%$ of the definition belongs to logic; $25 \%$ of the definition belongs to psychology; $10.9 \%$ of the definition belongs to education. Among of the disciplines, logic is much more than other disciplines. Why so much of the definitions of critical thinking belong to logic? That is a provoking question.

\subsection{The Time of Appearance of Critical Thinking}

The critical thinking came from Socrates. It does not mean that Socrates is the first person who started to study it. In fact, Goodwin Watson and E. M. Glaser did. They have the first definition of critical thinking, it included three parts: the first, a deep thinking attitude to problems appearing in the scope of human experience; the second, the knowledge of a logical questioning and inference method; (3) using the logical questioning and reasoning skills. The development trend of the definition of critical thinking is neither up nor down; it always changes from 1941 to 2013 in figure 3. There are seven definitions of critical thinking in 2002. It is the biggest number. From 1988 to 2013, every year at least has one definition of critical thinking. However, at the same period, the number of critical thinking has been over several hundreds of million. Although the study of the nature of critical thinking is a hard work, scholars never stop studying the nature of critical thinking. The study of the nature of critical thinking is a hard work. Based on the data from line chart, it can be concluded the number of the definition of critical thinking will not go beyond 10 in the following year.

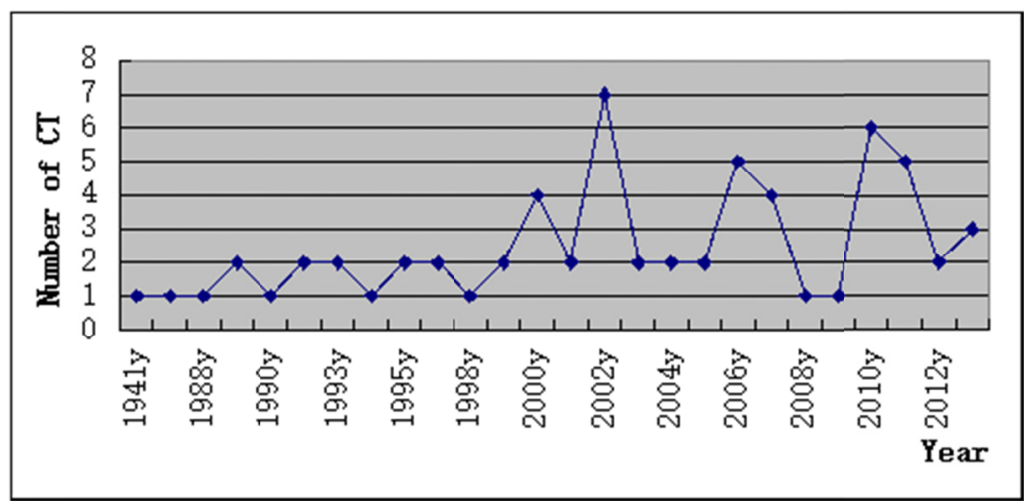

Figure 3. The time of appearance of critical thinking

\section{Discussion and Recommendation}

This paper has focused on three aspects of the definition of critical thinking. It offers several significance; firstly, it contributes to the nature of critical thinking. This study makes clear that scholars often use "judgment" in their definition of critical thinking. Critical thinking is judged in terms of how well it reaches certain standards or criteria for what is considered sound or good critical thinkers (Bensely, 2011). Reflection on the quality of thinking in relation to criteria and standards is important to self -correction in critical thinking (Lipman, 1991). Every sort of nature of the definition of critical thinking emphasized different focus. Which is on earth the real nature of critical thinking, among the judgment, argument, questioning, information processing, meta-cognition, problem solving and "skill and disposition". It will be worth studying.

Secondly, there are different natures due to the author from the different disciplines. It has a direct relationship between discipline and the nature of critical thinking, even in two sorts of the nature of critical thinking. Halpern (2007) who is a psychologist has included skills for problem solving, decision making, and creativity in his definition of critical thinking. In contrast, Ennis who is a philosopher listed no skills for the definition of critical thinking. Judgment is one of the three forms of thinking in formal logic. Argument is from informal logic, it is the main content of informal logic (Xiong, 2006). The development of the informal logic movement in logic 
commonly associated with critical thinking has focused on teaching people to reason well and to identify fallacies in natural language discourse (Emeren, 1996).

The last one, but the most important one is interdisciplinary research of nature of critical thinking. Scholars from different disciplines often have the same topic of the nature of critical thinking, but the difference is that they employed different perspectives or methods, and they have different conclusions. The most obvious example is APA Delphi panel, composed mostly of philosophers, thought that critical thinking is related to problem solving, decision making, and creative thinking like Halpern (Facione, 1990) Philophers and educators usually recommend students, especially college students follow certain principles and rules to produce thinking that meet prescribed standards while psychologists take a descriptive approach when scientifically studying how people think, sometimes investigating how well people can use the rules of reasoning and documenting their thinking errors in relation to norms (Galotti, 1989). It concluded that philosophers and educators pay more attention to what people will follow when they think and psychologists emphasized on how people think. These selective definitions of critical thinking show that most of the authorities agree that critical thinking involves certain skills, especially skills for reasoning well. In a word, many philosophers, educators and psychologists agree that acquiring critical thinking skill is important to the definition of critical thinking, but disagreements multiply when those definitions of critical thinking seek to identify specific skills that should be part of a critical thinker's skill set (Bailin, 1999).

Although the number of the research of critical thinking is so tremendous, the critical thinking especially is still paid more and more attention and the present study has come out with a number of recommendations.

First, the nature of critical thinking should be thought as the most important and at the heart of all the research.

Second, setting up an organization of interdisciplinary research of critical thinking and recruiting the scholars who has multi-disciplinary background to research in critical thinking. They should do interdisciplinary research of the nature of critical thinking and others.

Third, the organization of interdisciplinary research should provide help in promoting the research of critical thinking in different countries all over the world.

\section{Conclusion}

The tremendous number of critical thinking has confused students, teachers and instructors. So, it is an eager need to study the nature by the definition of critical thinking. Based on 64 definitions of critical thinking in the recent study, it can be concluded that scholars take judgment, argument, questioning, information processing, problem solving, meta-cognition, skill and disposition as the nature of critical thinking. Scholar's disciplinary background directly affect their opinions of critical thinking, interdisciplinary research should be paid more attention to promote the development of critical thinking.

\section{References}

Bailin, S., Case, R., Coombs, J. R., \& Daniels, L. B. (1990). Common miscoceptions of critical thinking. Journal of Curriculum Studies, 31, 269-283. http://dx. doi.org./10.1080/002202799183124.

Bensely, D. A. (2009). Thinking critically about critical thinking approaches: Comment on Yancher, Slife, and Warne. Review of General Psychology, 13, 275-277. http://dx.doi.org./10.1037/a0015654

Bensely, D. A. (2011). Rules for reasoning revisited: toward a scientific conception of critical thinking. In C. P. Horvath \& J. M. Forte (Eds.), Critical thinking: Education in a competitive and globalizing world (pp. 1-45). New York, NY: Nova Science Publishers.

Beyer, B. K. (1995). Critical thinking. Fastback (Vol. 385, pp. 7-33). Bloomington, IN: Phi Delta Kappa Education Foundation.

Chance, P. (1986). Thinking in the classroom: A survey of programs. New York, NY: Teachers College Press.

Cody, D. F. (2006). Critical thoughts on critical thinking. The Journal of Academic Librarianship, 32, 403-407. http://dx.doi.org./10.1016/j.acalib.2006.03.007.

Dong, Y. (2012, November 15). Three fundamental misconceptions of critical thinking. Higher Education Research, 33(11), 64.

Eemern, F. H., Van grootendorst, R., Henkemans, F. H., Blair, J. A., Johnson, R. H., Krabbe, E. C., \& Zarefsky, D. (1996). Fundamnetals of argumentation theory: A handbook of historical backgrounds and contemporary developments. Mahwah, NJ: Erlbaum.

Ennis, R. H. (1987). A taxonomy of critical thinking dispositions and abilities. In J. B. Baron, \& R. F. Sternberg 
(Eds.), Teaching thinking skills: Theory and practice (pp. 9-26). New York, NY: Freeman.

Facione, P. A. (1990). Critical Thinking: A Statement of Expert Consensus for Purposes of Educational Assessment and Instruction. Millbrae: The California Academic Press.

Fisher, A. (2000). Critical Thinking: An Introduction. Cambridge, UK: Cambridge University Press.

Galotti, K. M. (1989). Approaches to studying formal and informal reasoning. Psychological Bulletin. 105, 331-351. http://dx.doi.org./10.1037/0033-2909.105.3.331.

Glaser, E. M. (1941). An experiment in the development of critical thinking. New York, NY: Bureau of Publications, Teachers College, Columbia University.

Halpern, D. F. (n. d.). The nature and nurture of critical thinking. In R. Sternberg, H. Roediger, \& D. Halpern (Eds.), Critical thinking in psychology (pp. 1-14). Cambridge, UK: Cambridge University Press.

Johnson, R. H. (1992). The problem of defining critical thinking. In S. P. Norris (Ed.), The generalizability of critical thinking: Multiple perspectives on an educational ideal. New York, NY: Teachers College Press.

Johnson, R. H. (1993). Creative and critical thinking through academic controversy. American behavioral Scientist, 1, 40-54. http://dx.doi.org./10.1177/0002764293037001005.

Kurfiss J. G. (1988). Critical Thinking: Theory, Research, Practice, and Possibilities ASHE-ERIC Higher Education Report NO. 2. Washington, D. C.: Association for the Study of Higher Education.

Lipman, M. (1991). Thinking in education. Cambridge, UK: Cambridge University Press.

Paul, R., \& Elder L. (1999). Critical thinking: Teaching student to seek the logic of things. Journal of Developmental Education, 1, 34-35. Retrieved August 19, 2014, from http://eric.ed.gov/?id=EJ593592

Paul, W., \& Elder R. (2006). Critical thinking: Learn the tools the best thinkers use. New Jersey, NJ: Pearson Prentice Hall.

Petris, K. (2004). Critical thinking: An extend definition. Education, 124, 461-466. Retrieved August 19, 2014. From http://isites.harvard.edu/fs/docs/icb.topic265890.files/Critical_Thinking_File/06_CT_Extended_Definition. pdf

Riddell, T. (2007). Critical assumptions: Thinking critically about critical thinking. Journal of Nursing Education, 46, 121-126. Retrieved August 19, 2014, from http://europepmc.org/abstract/med/17396551.

Scriven, M. (2000). Learning theories: An educational perspective. Upper Saddler river, NJ: Prentice-Hall.

Williams, R. L., \& Worth, S. L. (2001). The relationship of critical thinking to success in college. Inquiry: Critical Thinking across the Disciplines, 21, 5-16. Retrieved August 19, 2014, from http://www.pdcnet.org/inquiryct_poiesis/content/inquiryct_poiesis_2001_0021_0001_0005_0016.

Xiong, M. (2006, Februray 28). The relationship between critical thinking and logic. Modern philosophy, 2, 115-119.

Zhang, C. (1989). Psychology Dictionary. Taibei, TB: Donghua Press.

Zhu, Z., \& Lin, C. (2002). Thinking development psychology. Beijing, BJ: Beijing Normal University Press.

\section{Copyrights}

Copyright for this article is retained by the author(s), with first publication rights granted to the journal.

This is an open-access article distributed under the terms and conditions of the Creative Commons Attribution license (http://creativecommons.org/licenses/by/3.0/). 